\title{
Experimental study of Optimum Working Temperature Range of Deep Cycled Lead Acid Solar Battery
}

\author{
J. A. Amusan ${ }^{1 *}$ and E. B. Otokunefor ${ }^{2}$ \\ Department of Physics \\ University of Port Harcourt \\ P. M. B. 5323, East - West Road, Choba \\ Port Harcourt, Rivers State, Nigeria
}

\begin{abstract}
The optimum working temperature range of deep cycled lead acid solar battery was studied. A 4- different model of deep cycled Lead acid battery of $12 \mathrm{~V}, 100 \mathrm{amp}$-hr was used along $250 \mathrm{Watts}$ mono crystalline silicon solar panel. A digital multimeter, charge controller, 250 Watts incandescent bulb (load), inverter and a digital thermometer were employed in the study. The experimental set-up was done in the environ of University of Port-Harcourt (Latitude $4^{0} 55^{\prime} 58^{\prime}$ 'N and Longitude $6^{0} 599^{\prime} 55^{\prime}$ 'East), Rivers State, Nigeria (tropical climate region). The measured voltage and temperature during charging and discharging processes consequently determine the charging and discharging efficiency of the battery. Through this, the optimum working temperature range of the considered Lead Acid battery falls within $29^{\circ} \mathrm{C}$ and $37^{\circ} \mathrm{C}$.
\end{abstract}

Keywords: Voltage, Temperature, Charge Efficiency, Discharge Efficiency, Deep Cycled battery.

\section{INTRODUCTION}

A battery is an electrical device that stores chemical energy for further use as electrical energy. Battery does not generate electricity but converts chemical energy into electricity by the use of galvanic cell. A galvanic or voltaic cell is a simple device that consists of two electrodes, anode and cathode in an electrolyte solution.

Batteries convert the chemical energy contained in its active materials into electrical energy by an electro-chemical oxidation-reduction reverse reaction [1].

Batteries are basically characterized into two, namely, Primary and Secondary cells. A collection of cells make up a battery. Primary battery remains unusable after the stored energy had been exhausted through usage while the secondary battery can be reused several times by recharging the battery. Recharging a secondary battery would require a 'charger' having a little voltage higher than the cell voltage of the battery. Charging of a battery is achieved by passing current through the circuit in the opposite direction to the current through the discharging process.

The historical developments of some batteries were reported by some researchers such as Baghdad battery [2], Linked Capacitors [3], Trough battery [4], Volta's pile [5], Zinc Copper Voltaic pile [6], Daniel cell [7], Bird's cell [8], Porous pot cell [7], Gravity cell [6] and Groove cell [6]. [9] outlined the complete history of the development of the current battery system.

Researchers are currently making efforts to improve the performance of the battery in terms of energy density, weight and effective less cost. The battery performance can be improved by considering the materials employed as electrodes, electrolytes and packaging during production.

Deep cycled batteries are designed to be cycled (discharged and recharged) many times while a shallow or starter battery (such as car battery) is designed to deliver a burst of energy for a short time. Deep cycled battery provides power at a steady state over a long period.

The Starting, Lighting and Ignition (SLI) Lead acid batteries are used in automobiles for starting the engines, running the light and various electronics [10]. 
There are at least six major rechargeable electrochemistries available today. They are Lead Acid (Pb - acid), Nickel Cadmium (Ni Cd), Nickel Metal Hydride (NiMH), Lithium ion (Li-ion), Lithium- polymer (Li-poly) and Zinc air [11].

Lead Antimony battery uses Antimony as the basic alloy element located between the two plates of grid. The addition of Antimony improves the flexibility of the metal and tensile strength of the grid with high discharge rate performance [12]

Also, Lead Calcium alloy has been the most widely used alloy in many Antimony free good batteries [12].

Lead Antimony/Lead Calcium hybrid combines the numerous advantages from that of Lead-calcium and LeadAntimony batteries [13] in that it has a very good deep cycle performance, low water loss and long life.

Different types of deep cycle batteries are flooded batteries, Gel batteries, absorbent Glass Mat (AGM) batteries.

Deep cycle batteries have common storage option for mini or micro-grids or the grid independent electrical power systems, uninterrupted power supply and springing reserved applications [14].

Each electrochemistry has its advantages and drawbacks. The choice of a particular electrochemistry depends on its applicability, availability and cost. Amongst the available battery electrochemistries, [15] characterized the performance of deep cycled Lead Acid batteries through voltages and round -trip energy efficiency for solar power applications.

Generally, it has been observed that a battery kept for a long time even without use will eventually lose all its charge. The leakage or self discharge varies considerably with battery types, age and temperature.

Temperature thus plays an important (if not critical) in the battery performance. The effect of temperature on battery voltage depends on the temperature variation and the materials that act as resistance. The effect of temperature on voltage is often used to release the electric current. When the terminals are connected, a chemical reaction is initiated and consequently generates electrons due to the potential difference between the terminals. As the temperature increases, rate of chemical reaction increases and the battery capacity generally increases usually at the cost of the battery life span.

Each battery electrochemistry perhaps offers optimum working temperature for its operation. This paper thus reports the optimum working temperature range of some selected deep cycled Lead acid solar batteries that are available in today's market.

\section{MATERIALS AND METHOD}

In determining the optimum working temperature range of deep cycle Lead acid solar battery, some electrical and electronic devices were employed. Table 1 presents the list of the materials/devices and their specifications.

Table 1: Device list and specifications

\begin{tabular}{|l|l|l|l|}
\hline S/N & \multicolumn{1}{|c|}{ DEVICE } & \multicolumn{1}{|c|}{ CAPACITY } & QUANTITY \\
\hline 1 & Solar Module & 250 Watts/Monocrystalline & 4 \\
\hline 2 & Power Inverter & $5 \mathrm{KVA} / 12 \mathrm{~V}$ Doxin & 1 \\
\hline 3 & Digital Multimeter & DT 9205A CE & 2 \\
\hline 4 & Deep Cycle Lead Acid Battery & 100 Amp-hr / 12V & 4 \\
\hline 6 & Electrical Cable & $2 \mathrm{AWG}(\mathrm{American}$ Wire Guage $)$ & $10 \mathrm{~m}$ \\
\hline 7 & Digital Thermometer & $-50^{\circ} \mathrm{C}-30^{\circ} \mathrm{C} / 1.5 \mathrm{~V}$ & 2 \\
\hline 8 & Incandescent bulb & $250 \mathrm{~W} / 220 \mathrm{~V}$ & 1 \\
\hline 9 & Clock & Digital & 1 \\
\hline
\end{tabular}


Before device connection, the open circuit voltage, Voc, of the employed solar panel was measured with digital multimeter. Also, the batteries terminal voltage without load were measured and recorded. After the initial battery and solar panel's voltages were taken, the solar panel was connected directly to the battery tightly and allowed to charge the battery for aperiod of 15 minutes. The solar panel was disconnected so that the voltage of the solar panel and the battery can be measured independently. Digital thermometer was employed to measure the temperature of the solar panel and that of the battery at each period of voltage measurement. This procedure was repeated successively at interval of 15 minutes.

During discharging process of the Lead Acid battery, firstly, the solar panel was disconnected from the battery. The battery terminal voltage and the temperature were measured without any load connected to it. Then, the power inverter was connected appropriately to the battery and a 250 Watts load (incadescent bulb) was plugged into the inverter. The inverter was switched on and the bulb glew. After every 15 minutes, the voltage and corresponding temperature were recorded from the battery terminals. This procedure was repeated successively until the energy in the battery was exhausted. Figures 1 and 2 show the experimental set-up in -situ.

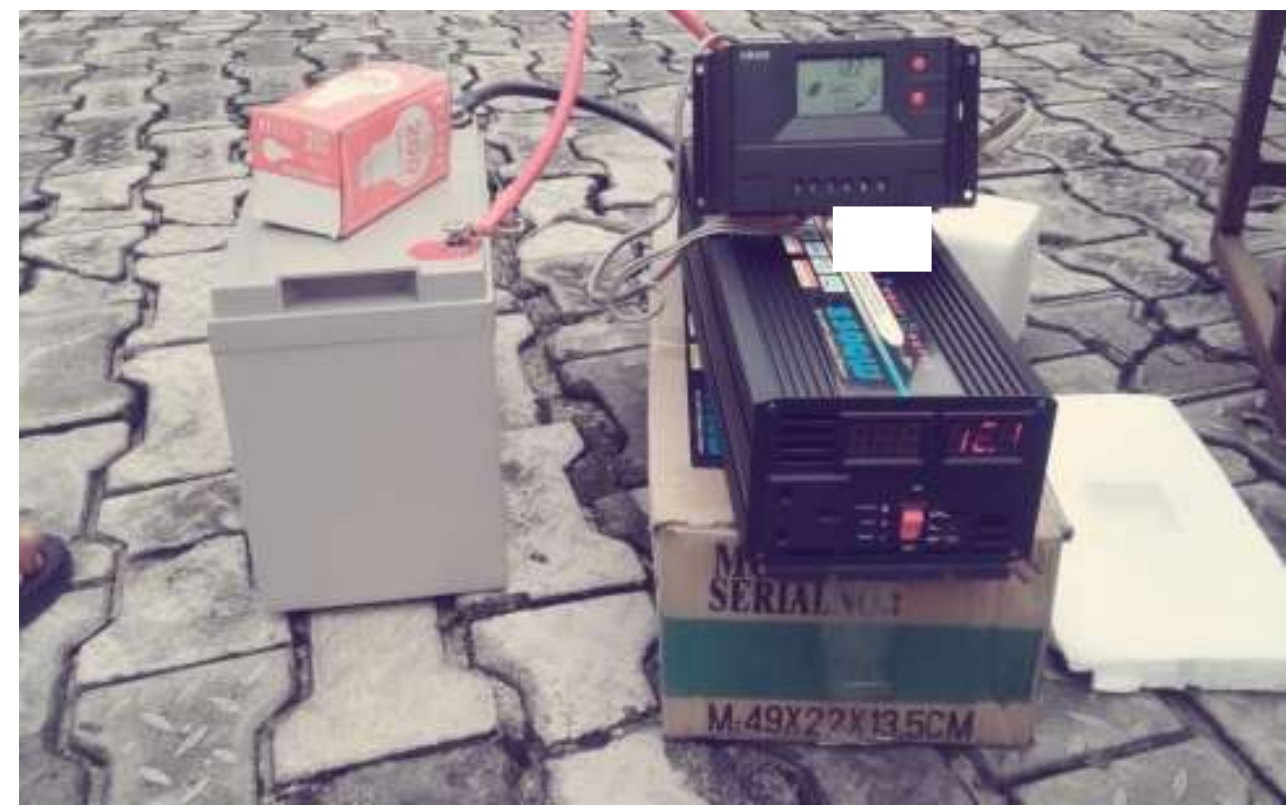

Figure 1: Front view of set up for a typical battery.

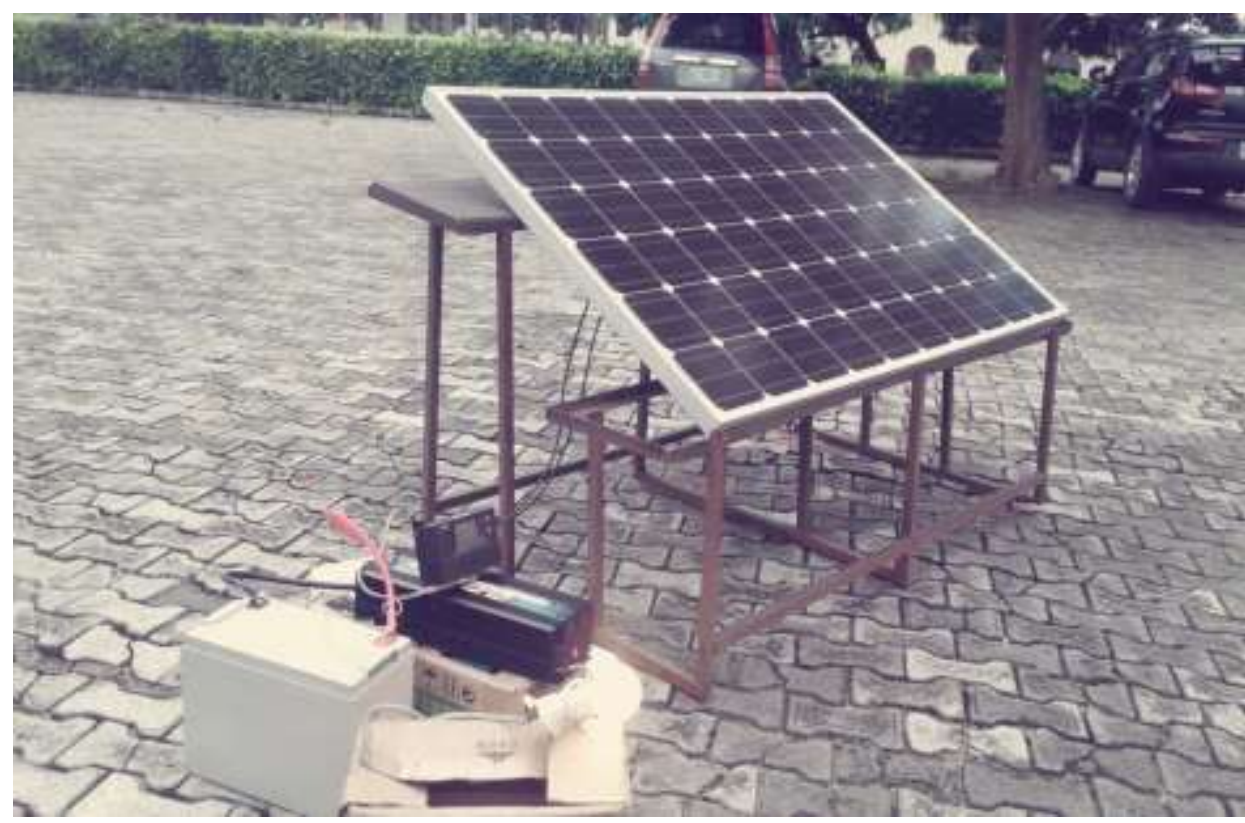

Figure 2: Side view of set-up for a typical battery.

After measurements, the charge efficiency was determined using equation 1. 
International Journal of Advances in Scientific Research and Engineering (ijasre), Vol 5 (4), April-2019

$$
\text { Charge Efficiency }(\%)=\frac{V_{c}}{V_{o c}} \times 100
$$

Also, the discharge efficiency was determined using equation 2 .

$$
\text { Discharge Efficiency (\%) }=\frac{V_{\text {present }}}{V_{\text {previous }}} \times 100
$$

\section{RESULTS}

The results of typical Sunvolt technology Lead Acid battery were tabulated as shown in Tables 2, 3 and 4.

\begin{tabular}{|c|c|c|c|c|}
\hline Time (Min) & $\begin{array}{l}\text { Battery voltage } \\
\qquad V_{C}\end{array}$ & $\begin{array}{c}\text { Battery } \\
\text { temperature } \\
\mathbf{T}_{\mathrm{C}}\end{array}$ & $\begin{array}{c}\text { Solar Panel Voltage } \\
\text { V OC }_{\text {OC }}\end{array}$ & $\begin{array}{c}\text { Charge efficiency } \\
(\%) \\
\frac{V_{C}}{V_{O C}} * \frac{100}{1}\end{array}$ \\
\hline 9.00 a.m & 11.96 & 27.60 & 17.64 & 67.80 \\
\hline 9.15 a.m & 12.13 & 28.50 & 17.70 & 68.53 \\
\hline 9.30 a.m & 12.15 & 29.20 & 17.68 & 68.72 \\
\hline 9.45 a.m & 12.18 & 29.40 & 17.67 & 68.93 \\
\hline 10.00 a.m & 12.22 & 29.60 & 17.64 & 69.27 \\
\hline 10.15 a.m & 12.23 & 30.02 & 17.65 & 69.29 \\
\hline 10.30 a.m & 12.22 & 30.05 & 17.60 & 69.43 \\
\hline 10.45 a.m & 12.21 & 30.40 & 17.58 & 69.45 \\
\hline 11.00 a.m & 12.25 & 31.04 & 17.78 & 68.89 \\
\hline 11.15 a.m & 12.26 & 31.02 & 17.64 & 69.50 \\
\hline 11.30 a.m & 12.30 & 31.30 & 17.50 & 70.29 \\
\hline 11.45a.m & 12.32 & 31.58 & 17.52 & 70.32 \\
\hline 12.00 noon & 12.34 & 31.70 & 17.42 & 70.84 \\
\hline 12.15 p.m & 12.36 & 31.74 & 17.46 & 70.80 \\
\hline 12.30 p.m & 12.35 & 31.94 & 17.46 & 70.73 \\
\hline 12.45 p.m & 12.36 & 32.20 & 17.72 & 69.75 \\
\hline 01.00 p.m & 12.37 & 32.60 & 17.77 & 69.61 \\
\hline 01.15 p.m & 12.40 & 33.40 & 17.74 & 69.89 \\
\hline 01.30 p.m & 12.42 & 34.50 & 17.73 & 70.05 \\
\hline 01.45 p.m & 12.45 & 34.70 & 17.75 & 70.14 \\
\hline 02.00 p.m & 12.47 & 36.50 & 17.74 & 70.29 \\
\hline 02.15 p.m & 12.50 & 37.02 & 717.2 & 70.54 \\
\hline 02.30 p.m & 12.52 & 37.80 & 17.78 & 70.42 \\
\hline 02.45 p.m & 12.54 & 36.62 & 17.94 & 69.90 \\
\hline 03.00 p.m & 12.60 & 36.72 & 18.06 & 69.77 \\
\hline 03.15 p.m & 12.64 & 37.02 & 18.20 & 69.45 \\
\hline 03.30 p.m & 12.70 & 36.40 & 18.36 & 69.17 \\
\hline 03.45 p.m & 12.84 & 37.60 & 18.42 & 69.70 \\
\hline 04.00 p.m & 12.96 & 37.64 & 18.16 & 71.37 \\
\hline 04.15 p.m & 13.02 & 37.77 & 18.40 & 70.76 \\
\hline 04.30 p.m & 13.24 & 36.94 & 17.98 & 73.64 \\
\hline 04.45 p.m & 13.44 & 37.04 & 17.96 & 74.83 \\
\hline
\end{tabular}

Table 2: Typical data acquired during charging of Lead Acid Battery: Sunvolt Technology 
International Journal of Advances in Scientific Research and Engineering (ijasre), Vol 5 (4), April-2019

Table 3: Typical data acquired during discharging of Lead Acid Battery: Sunvolt Technology

\begin{tabular}{|c|c|c|c|}
\hline $\begin{array}{l}\text { Time } \\
\text { (Min) }\end{array}$ & $\begin{array}{c}\text { Temperature } \\
\left(T_{d}\right)\end{array}$ & $\begin{array}{c}\text { Battery voltage } \\
\left(\mathbf{V}_{\mathrm{d}}\right)\end{array}$ & $\begin{array}{l}\text { Discharge efficiency } \\
\frac{\mathbf{V}_{\text {present }}}{\mathbf{V}_{\text {previous }}} * \frac{100}{1}\end{array}$ \\
\hline 9.00 a.m & 28.60 & 13.40 & \\
\hline 9.15 a.m & 28.62 & 13.20 & 98.51 \\
\hline $9.30 \mathrm{a} . \mathrm{m}$ & 28.64 & 13.09 & 99.16 \\
\hline 9.45 a.m & 28.65 & 12.89 & 98.47 \\
\hline 10.00 a.m & 28.69 & 12.81 & 99.46 \\
\hline 10.15 a.m & 28.69 & 12.72 & 99.47 \\
\hline 10.30 a.m & 28.67 & 12.64 & 99.37 \\
\hline 10.45 a.m & 28.72 & 12.50 & 98.89 \\
\hline 11.00 a.m & 28.80 & 12.44 & 99.52 \\
\hline $11.15 \mathrm{a} . \mathrm{m}$ & 28.79 & 12.40 & 99.68 \\
\hline 11.30 a.m & 28.82 & 12.36 & 99.68 \\
\hline 11.45 a.m & 28.78 & 12.28 & 99.35 \\
\hline 12.00 noon & 28.82 & 12.19 & 99.26 \\
\hline 12.15 p.m & 28.12 & 12.06 & 98.93 \\
\hline 12.30 p.m & 28.40 & 11.78 & 97.6 \\
\hline 12.45 p.m & 28.48 & 11.72 & 99.50 \\
\hline 01.00 p.m & 28.52 & 11.64 & 99.30 \\
\hline 01.15 p.m & 28.62 & 11.52 & 98.97 \\
\hline 01.30 p.m & 28.72 & 11.41 & 99.05 \\
\hline 01.45 p.m & 28.84 & 11.28 & 98.86 \\
\hline 02.00 p.m & 29.04 & 10.98 & 97.34 \\
\hline 02.15 p.m & 29.76 & 10.84 & 98.72 \\
\hline 02.30 p.m & 29.31 & 10.76 & 99.26 \\
\hline 02.45 p.m & 29.36 & 10.62 & 98.70 \\
\hline 03.00 p.m & 29.60 & 10.44 & 98.31 \\
\hline 03.15 p.m & 29.64 & 10.31 & 98.75 \\
\hline 03.30 p.m & 29.74 & 10.22 & 99.10 \\
\hline 03.45 p.m & 29.81 & 9.79 & 95.79 \\
\hline 04.00 p.m & 29.77 & 9.60 & 98.06 \\
\hline 04.15 p.m & 29.86 & 9.06 & 94.38 \\
\hline
\end{tabular}

Table 4: Summarized data acquired during discharging and charging of Lead Acid Battery: Sunvolt Technology

\begin{tabular}{|c|c|c|c|c|c|c|c|}
\hline \multirow{2}{*}{$\begin{array}{l}\text { Time } \\
(\mathrm{MIN})\end{array}$} & \multicolumn{2}{|c|}{ Battery Charging } & \multirow{2}{*}{$\begin{array}{c}\text { Solar Panel } \\
\text { Voltage } \\
\mathrm{V}_{\mathrm{OC}}\end{array}$} & \multicolumn{2}{|c|}{ Battery Discharging } & \multirow{2}{*}{$\begin{array}{c}\text { Charge } \\
\text { efficiency }(\%) \\
\frac{V_{C}}{V_{O C}} * \frac{100}{1}\end{array}$} & \multirow{2}{*}{$\begin{array}{c}\text { Discharge Charge } \\
\text { efficiency } \\
\frac{V_{\text {present }}}{V_{\text {previous }}} * \frac{100}{1}\end{array}$} \\
\hline & $\mathrm{Vc}$ & $\mathrm{T}_{\mathrm{C}}$ & & $\mathrm{V}_{\mathrm{d}}$ & $\mathrm{T}_{\mathrm{d}}$ & & \\
\hline 9:00am & 11.96 & 27.60 & 17.64 & 13.40 & 28.60 & 67.80 & \\
\hline 9:15am & 12.13 & 28.50 & 17.70 & 13.20 & 28.62 & 68.53 & 98.51 \\
\hline 9:30am & 12.15 & 29.20 & 17.68 & 13.09 & 28.64 & 68.72 & 99.16 \\
\hline 9:45am & 12.18 & 29.40 & 17.67 & 12.89 & 28.65 & 68.93 & 98.47 \\
\hline 10:00am & 12.22 & 29.60 & 17.64 & 12.81 & 28.69 & 69.27 & 99.46 \\
\hline $10: 15 \mathrm{am}$ & 12.23 & 30.02 & 17.65 & 12.72 & 28.69 & 69.29 & 99.47 \\
\hline 10:30am & 12.22 & 30.05 & 17.60 & 12.64 & 28.67 & 69.43 & 99.37 \\
\hline $10: 45 \mathrm{am}$ & 12.21 & 30.40 & 17.58 & 12.50 & 28.72 & 69.45 & 98.89 \\
\hline 11:00am & 12.25 & 31.04 & 17.78 & 12.44 & 28.80 & 68.89 & 99.52 \\
\hline $11: 15 \mathrm{am}$ & 12.26 & 31.02 & 17.64 & 12.40 & 28.79 & 69.50 & 99.68 \\
\hline 11:30am & 12.30 & 31.30 & 17.50 & 12.36 & 28.82 & 70.29 & 99.68 \\
\hline $11: 45 \mathrm{am}$ & 12.32 & 31.58 & 17.52 & 12.28 & 28.78 & 70.32 & 99.35 \\
\hline 12:00pm & 12.34 & 31.70 & 17.42 & 12.19 & 28.82 & 70.84 & 99.26 \\
\hline
\end{tabular}


International Journal of Advances in Scientific Research and Engineering (ijasre), Vol 5 (4), April-2019

\begin{tabular}{|c|c|c|c|c|c|c|c|}
\hline $12: 15 \mathrm{pm}$ & 12.36 & 31.74 & 17.46 & 12.06 & 28.12 & 70.80 & 98.93 \\
\hline 1:00pm & 12.37 & 32.60 & 17.77 & 11.64 & 28.52 & 69.61 & 99.30 \\
\hline $1: 30 \mathrm{pm}$ & 12.42 & 34.50 & 17.73 & 11.41 & 28.72 & 70.05 & 99.05 \\
\hline $1: 45 \mathrm{pm}$ & 12.45 & 34.70 & 17.75 & 11.28 & 28.84 & 70.14 & 98.86 \\
\hline 2:00pm & 12.47 & 36.50 & 17.74 & 10.98 & 29.04 & 70.29 & 97.34 \\
\hline $2: 30 \mathrm{pm}$ & 12.52 & 37.80 & 17.78 & 1076 & 29.31 & 70.42 & 99.26 \\
\hline $2: 45 \mathrm{pm}$ & 12.54 & 36.62 & 17.94 & 10.62 & 29.36 & 69.90 & 98.70 \\
\hline 3:00pm & 12.60 & 36.72 & 18.06 & 10.44 & 29.60 & 69.77 & 98.31 \\
\hline $3: 15 \mathrm{pm}$ & 12.64 & 37.02 & 18.20 & 10.31 & 29.64 & 69.45 & 98.75 \\
\hline $3: 30 \mathrm{pm}$ & 12.70 & 36.40 & 18.36 & 10.22 & 29.74 & 69.17 & 99.10 \\
\hline $3: 45 \mathrm{pm}$ & 12.84 & 37.60 & 18.42 & 9.79 & 29.81 & 69.70 & 95.79 \\
\hline
\end{tabular}

The results obtained for another typical product of employed deep cycled Lead Acid batteries are shown in Tables 5. The other products are also analysed. 
International Journal of Advances in Scientific Research and Engineering (ijasre), Vol 5 (4), April-2019

Table 5: Summarized data acquired during discharging and charging of GLT deep cycled Lead Acid Battery.

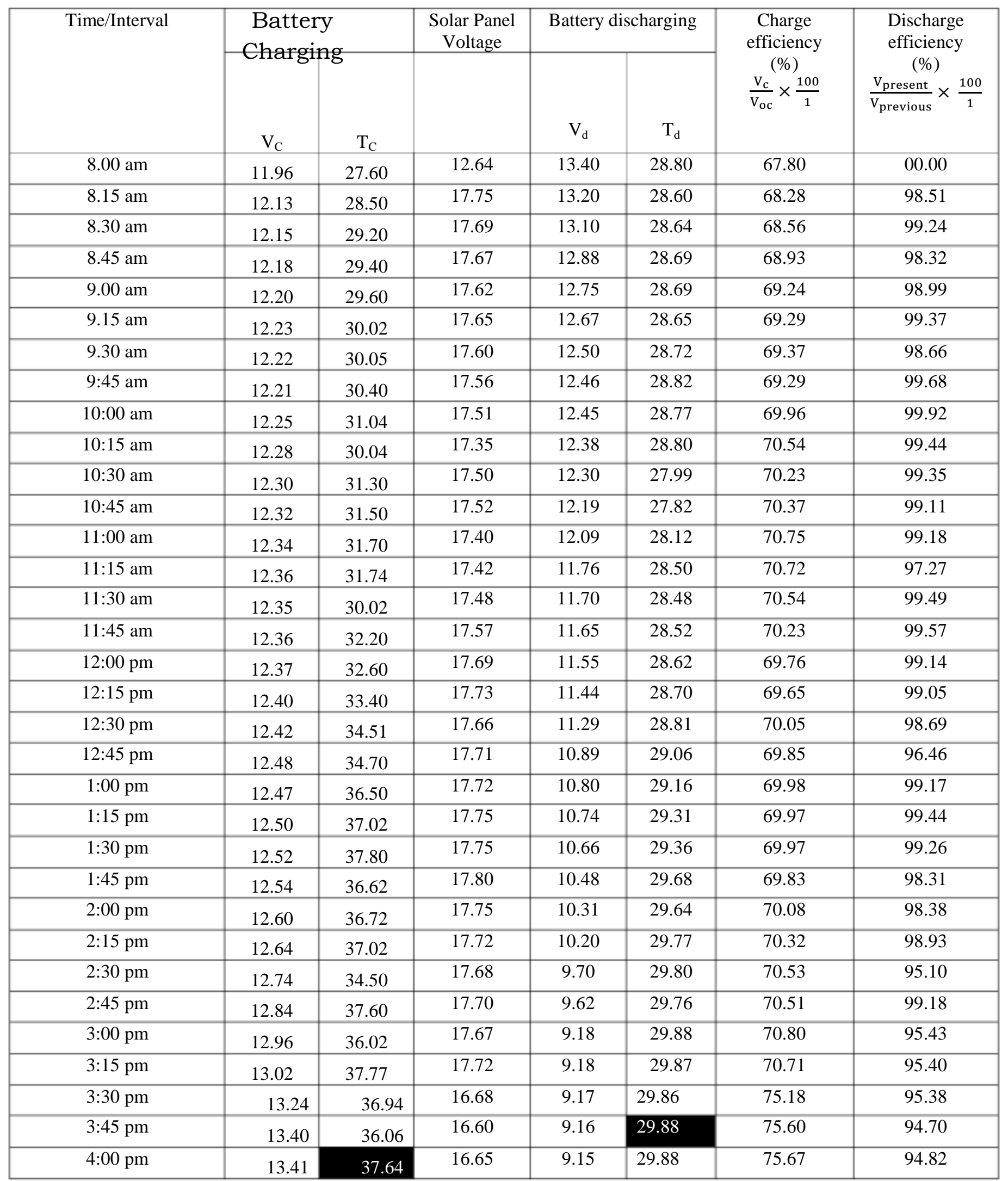




\section{DISCUSSION}

For a typical product (Sunvolt battery), the graph of battery temperature was plotted against battery voltage (Figure 3). Also, the battery temperature was plotted against charge efficiency (Figure 4).

From Figure 3, the battery temperature varies directly proportional to the battery voltage. At $12 \mathrm{~V}$, the battery temperature is $29^{\circ} \mathrm{C}$ and at $12.6 \mathrm{~V}$, the battery temperature is $34^{\circ} \mathrm{C}$. Also, at $13.4 \mathrm{~V}$, the battery temperature is $39^{\circ} \mathrm{C}$. This shows that increase in voltage during charging causes increase in temperature of the battery. As voltage rises, temperature also rises.

Figure 4 shows a direct variation. At $69 \%$, the battery temperature is $32^{\circ} \mathrm{C}$ and at $71 \%$, the battery temperature is $34^{\circ} \mathrm{C}$. Also, at $73 \%$, the battery temperature is $37^{\circ} \mathrm{C}$. This shows that during charging, increase in temperature causes increase in voltage and charge efficiency. Battery's voltage and charge efficiency increase linearly with increase in temperature.

Figure 5 is a graph of battery discharge voltage, Vd, plotted against discharge temperature, Td. At 10.7V, the battery temperature is $25^{\circ} \mathrm{C}$ and at $10.4^{\circ} \mathrm{V}$, the battery temperature is $27^{\circ} \mathrm{C}$. Also at $9.6 \mathrm{~V}$, the battery temperature is $30^{\circ} \mathrm{C}$. Thus, inverse relation exists. Decrease in battery voltage during discharge causes an increase in temperature of the battery.

Figure 6 presents discharge efficiency (\%) against temperature, Td. At $96 \%$, the battery temperature is $20^{\circ} \mathrm{C}$, and at $98 \%$, the battery temperature is $23{ }^{\circ} \mathrm{C}$. This direct relation shows that increase in temperature causes increase in discharge efficiency. Thus, the rate of discharge is high at high temperature.

Similar trends of relationship were obtained in the other products of employed deep cycle Lead Acid batteries.

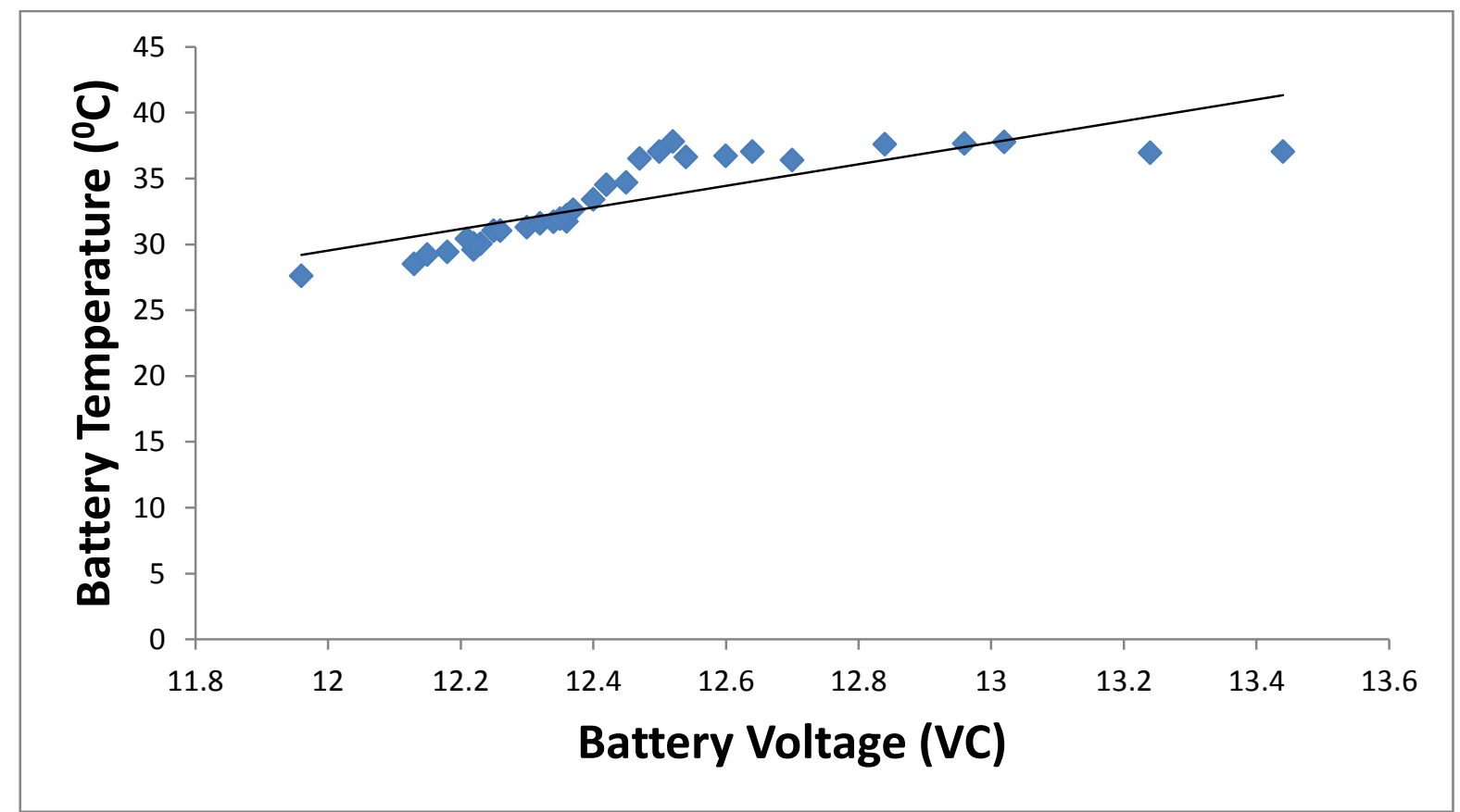

Figure 3: Battery temperature against voltage 
International Journal of Advances in Scientific Research and Engineering (ijasre), Vol 5 (4), April-2019

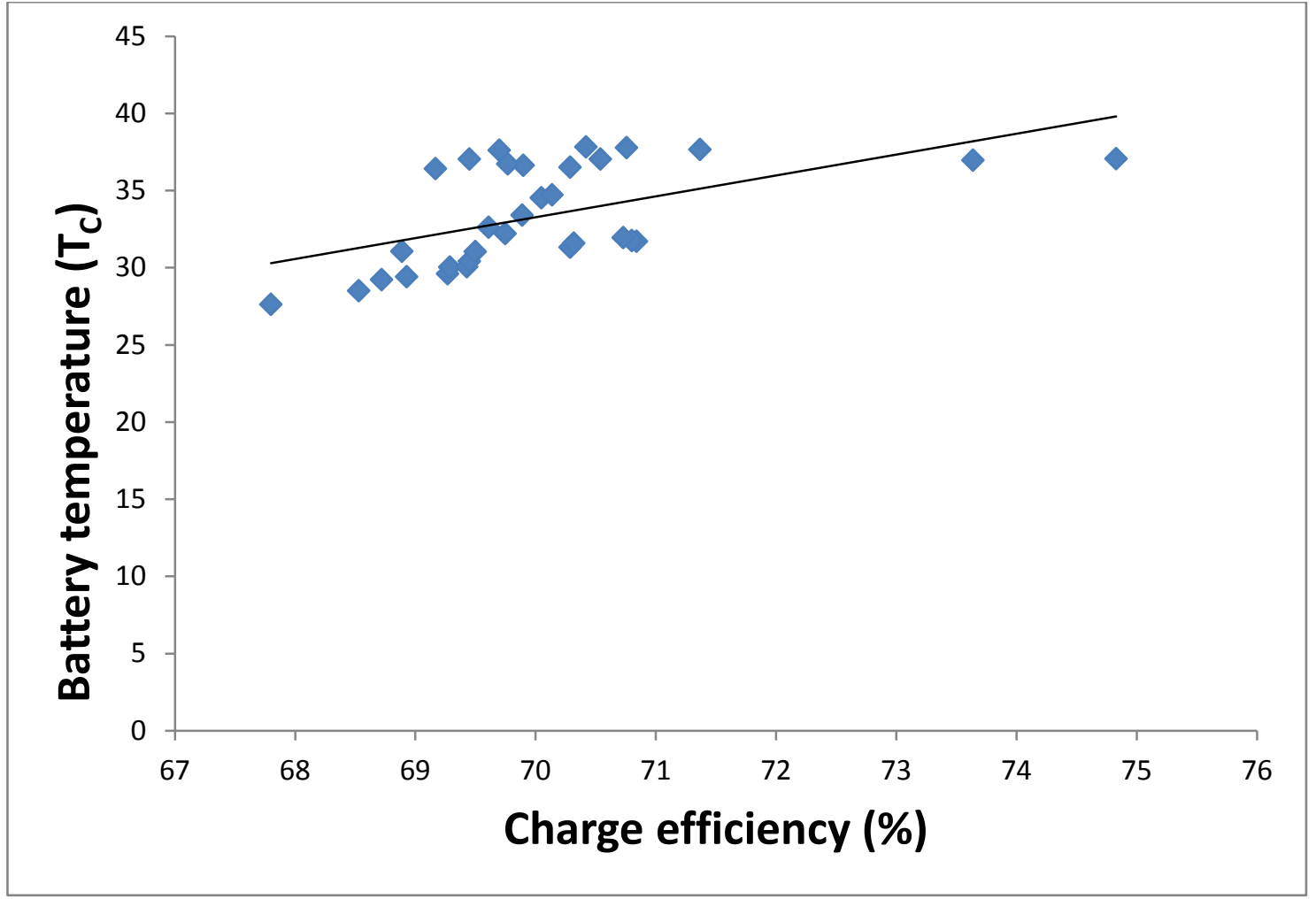

Figure 4: Battery's temperature against charging efficiency

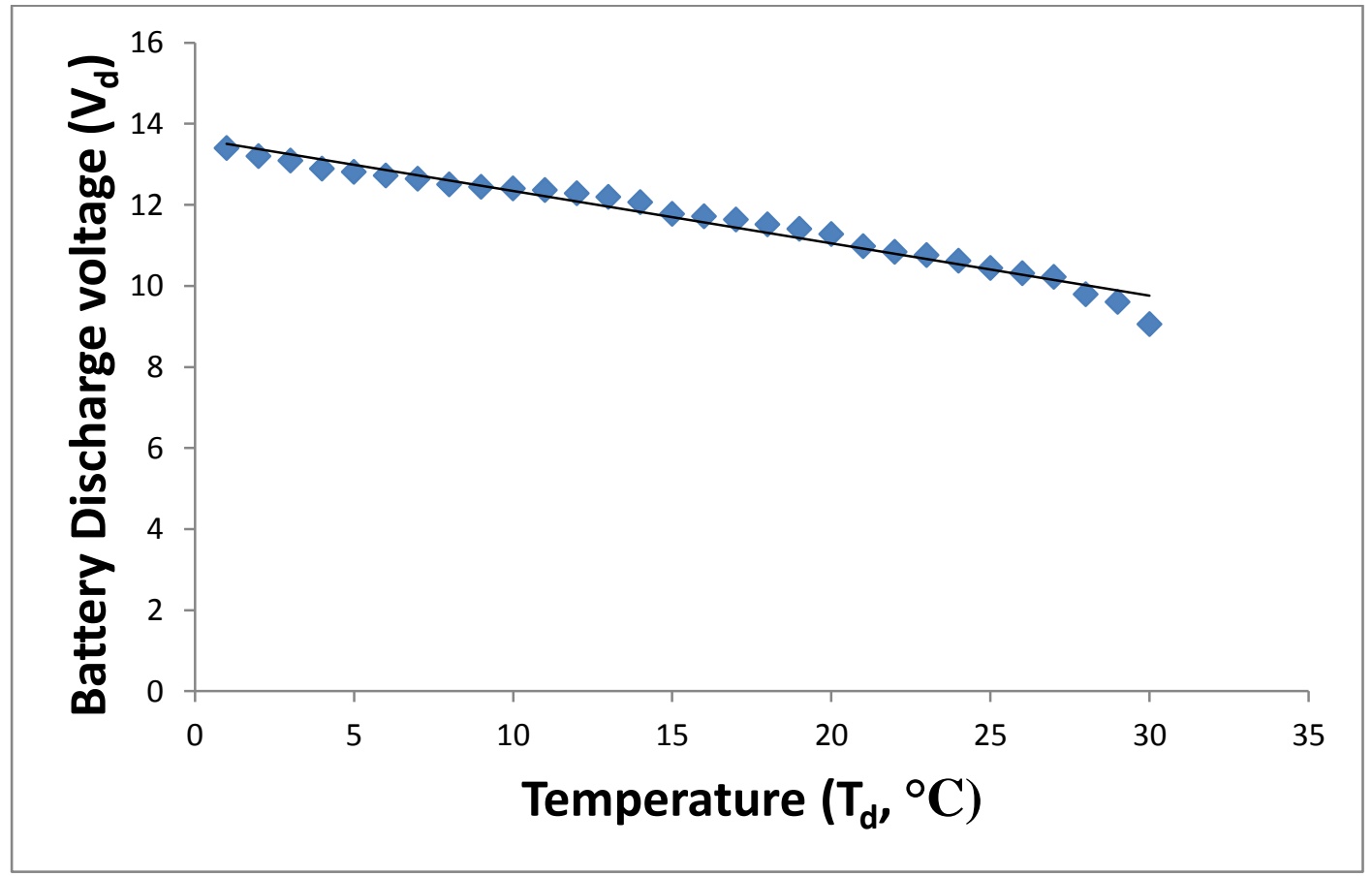

Figure 5: Battery Discharge voltage $\left(V_{d}\right)$ against Temperature $\left(T_{d}\right)$ 


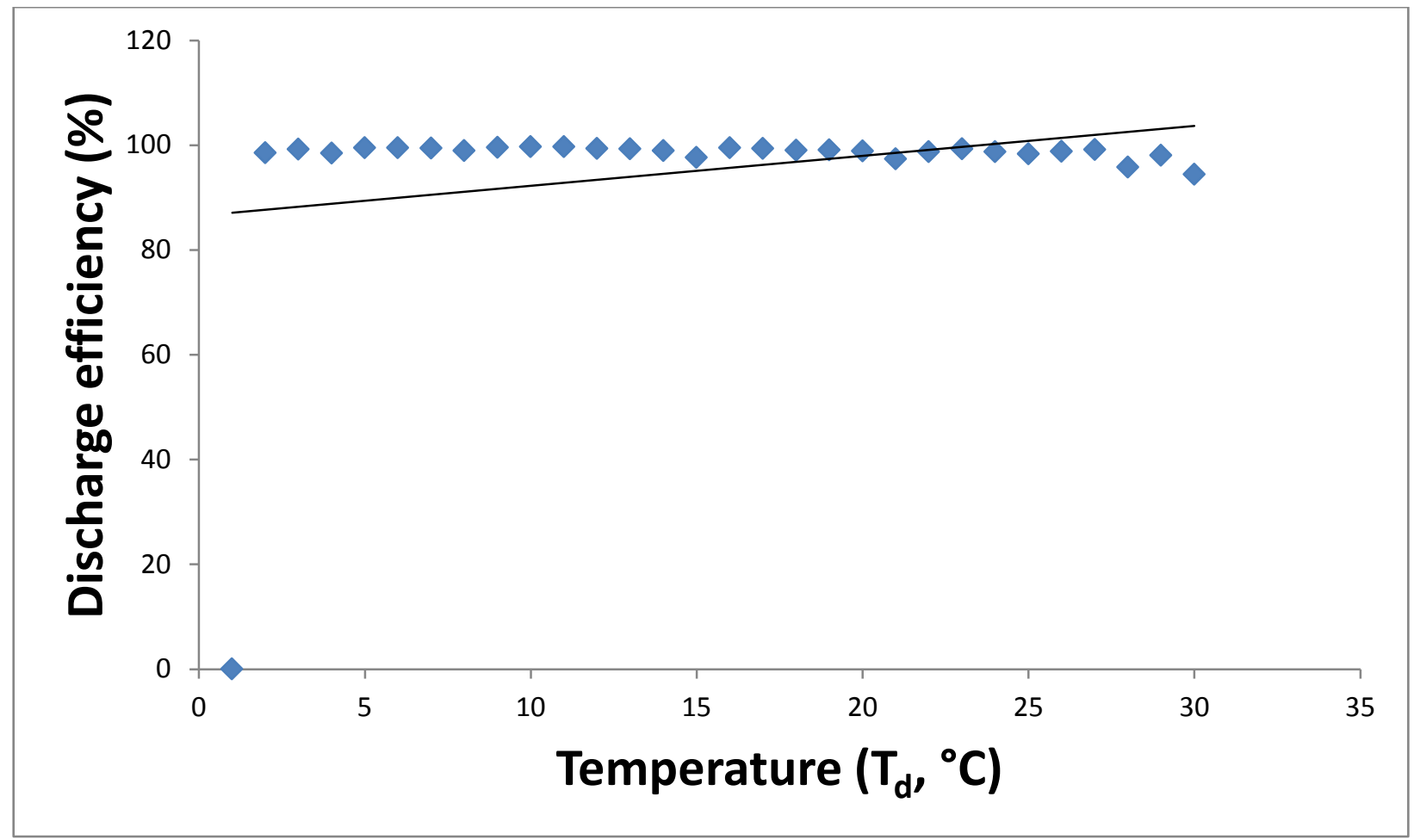

Figure 6: Battery discharge efficiency against Temperature $\left(\mathbf{T}_{\mathrm{d}}\right)$

The optimum working temperature of the deep cycled Lead acid battery was determined by considering the temperature at which the battery attained its maximum charge efficiency and minimum discharge efficiency for both the charging and discharging processes of the battery.

Table 6 presents the optimum working temperature range for 4 different deep cycled Lead acid batteries employed in the study.

Table 6: Optimum Working Temperature Range.

\begin{tabular}{|l|c|c|}
\hline \multicolumn{1}{|c|}{ S/N } & Model / Type of Battery & Temperature Range \\
\hline 1 & Zedix AGM & $30^{\circ} \mathrm{C}-35^{\circ} \mathrm{C}$ \\
\hline 2 & Sunvolt AGM & $29^{\circ} \mathrm{C}-37^{\circ} \mathrm{C}$ \\
\hline 3 & GLT AGM & $29.8^{\circ} \mathrm{C}-37.6^{\circ} \mathrm{C}$ \\
\hline 4 & Exclusive Gel & $34.5^{\circ} \mathrm{C}-37.6^{\circ} \mathrm{C}$ \\
\hline
\end{tabular}

The temperature range falls between $29^{\circ} \mathrm{C}$ and $37^{\circ} \mathrm{C}$. Optimum working temperature range falls within these temperature. Below and beyond these temperature affect the performance of deep cycle Lead acid solar battery.

\section{CONCLUSION}

Deep cycle Lead acid solar battery was considered in this study. Four different products were examined under the same operating conditions. The voltage and temperature of the battery were measured and recorded using digital multimeter and thermometer respectively during charging and discharging processes. The temperature at which the batteries attained its maximum charge efficiency was measured and recorded. Also, the temperature at which the batteries attained its minimum discharge efficiency was measured and recorded. Thus, the optimum working temperature range of the considered deep cycle Lead acid batteries falls within $29^{\circ} \mathrm{C}$ and $37^{\circ} \mathrm{C}$. In fact, each battery has its optimum working temperature as a result of different technologies and manufacturing process. 


\section{REFERENCES}

[1] Petr Krivik and Petr Boca (2013): Electrochemical Energy Storage, Intech Open, vol. 3, Pages 34 - 55. DOI : 10.5772/ 5222.

[2] Arran Frood (2003): Riddle of Baghdad's battery, BBC News (http://www.News.bbc.co.uk/2/hi/science/nature/2804257.stm.story).

[3] Benjamin Franklin (1749): The papers of Benjamin Franklin, New Haven Connecticut, Yale University Press, Vol. 3, Pages $237-253$.

[4] Bernard S. Finn (2002): origin of Electrical Power, National Museum of American History, page 347. http://american history.si.edu/powering/past/prehist.htm

[5] Decker Franco (2005): Volta and the Pie, 'Electrochemistry Encyclopedia', Case Western Reverse University, Page 78.

[6] James B. Calvert (2000): The electromagnetic Telegraph, Vol. 1, Page 15.

[7] Carboni Giorgio (1999): Experiments in Electro chemistry, Fun Science Gallery, Page 343.

[8] Watt, Alexander and Philip Arnod (2005): Electroplating and Electro refining of Metals, Watch-Maker Publishing, ISBN 1929148453, Pages 90 -92.

[9] Jeffery Oakes M. (2006): A brief history of Batteries and Stored Energy. Neta World Summer, Vol. 2 , Pages 1 - 6.

[10] Ross Kerly (2014): Automotive Lead Acid battery, Vol. 2, Pages 15 - 37, DOI: 10.1109/IECON.2015.7392714

[11] Patel, Mukund R. (2006): Wind and Solar Power System, CRC Press, Boca Raton, London, ISBN-10: 0-8493 - 1570, Page 210.

[12] Janakiraman R., Balakrishman P. G., Derasahayam M. Palanichamy (1988): Lead Calcium Alloy for Lead Acid Battery: Effect of Additives on Cycling, B. Electrochem 4(6) June 1988, Pages 563 - 564.

[13] James D. Dunlop (1997) : Batteries and Charge Controller in Stand-Alone Photovoltaic System Fundamentals and Applications, Florida Solar Energy Centre, FSEC - CR - 1292 - 01, Vol. 2, No: 32922, Pages 1 - 71.

[14] Tollyat A. and Kwasinki (2015): Energy Storage Sizing for Effective Primary and Secondary Control of Low-Inertia micro-grids. In proceedings of the IEEE, $6^{\text {th }}$ International Sympossium on Power Electronic for Distributed Generation System, Aachem, Germany, 22 June 2015, Pages $1-3$.

[15] Amusan, J. A. and Igbudu, O. (2015): The Performance Characteristics of Lead Acid Deep Cycle Batteries through Voltages and Round-Trip Energy Efficiency for Solar Power Application, Scientia Africana, Vol. 14 (No. 2), Pages 143 $-156$. 